\title{
NCKAP1 wt Allele
}

National Cancer Institute

\section{Source}

National Cancer Institute. NCKAP1 wt Allele. NCI Thesaurus. Code C138141.

Human NCKAP1 wild-type allele is located in the vicinity of 2q32.1 and is approximately $130 \mathrm{~kb}$ in length. This allele, which encodes Nck-associated protein 1, plays a role in endocytosis and lamellipodia formation. 